\title{
Protease Inhibitors Suppress the In Vitro and In Vivo Replication of Rotavirus
}

\author{
S. L. Vonderfecht, ${ }^{\star *}$ R. L. Miskuff, ${ }^{*}$ Siok-Bi Wee, ${ }^{5}$ S. Sato, ${ }^{5}$ R. R. Tidwell," J. D. Geratz," and R. H. Yolken \\ ${ }^{*}$ Division of Comparative Medicine, ${ }^{\ddagger}$ Department of Pathology, and ${ }^{\S}$ Division of Pediatric Infectious Diseases, Johns Hopkins \\ University School of Medicine, Baltimore, Maryland 21205; and the "Department of Pathology, University of North Carolina, \\ School of Medicine, Chapel Hill, North Carolina 27514
}

\begin{abstract}
Rotaviruses are major causes of infectious gastroenteritis in humans and other animals. We found that a variety of protease inhibitors suppressed the replication of the SA-11 strain of rotavirus in MA-104 cell cultures. Three of these compounds, leupeptin, pentamidine, and bis (5-amidino-2-benzimidazolyl) methane (BABIM) also restricted the intestinal replication of the murine strain of rotavirus when protease inhibitor and virus were administered simultaneously to suckling mice. Repeated administration of BABIM resulted in significantly reduced levels of intestinal rotaviral antigen even if administration of the compound was begun as late as $48 \mathrm{~h}$ after viral inoculation. Additionally, BABIM-treated animals had significantly less intestinal replication of rotavirus than did placebotreated controls when placed in a heavily rotavirus-contaminated environment. The use of protease inhibitors represents a novel approach to the control of this important gastrointestinal pathogen and is a potential modality for the prevention and treatment of diseases caused by other enteric viruses, for which proteolytic cleavage is necessary for efficient replication.
\end{abstract}

\section{Introduction}

Rotaviruses are double-stranded RNA viruses of the family Reoviridae that have been implicated as important causative agents of acute gastroenteritis in humans and other animals (1-3). Numerous epidemiological studies have indicated that rotaviruses are a major cause of morbidity in children living in developed countries and of serious and potentially fatal gastroenteritis in children living in the developing areas of the world (4-6). Additionally, these viruses have been implicated as causative agents of gastroenteritis occurring in nursing homes $(7,8)$, travelers $(9,10)$, adult contacts of ill children $(11$, 12 ), and have been identified as etiologic agents of severe gastroenteritis in patients rendered immunodeficient because of cancer chemotherapy or other immunodeficiency conditions $(13,14)$. Because of the importance of rotavirus infections, intensive efforts have been directed at developing attenuated strains of rotavirus that might be capable of providing longterm immunity after oral administration $(15,16)$. However, it

This work was presented in part at the Annual Meeting of the Society for Pediatric Research, 1986.

Address reprint requests to Dr. Robert Yolken, Division of Pediatric Infectious Diseases, Johns Hopkins University, Baltimore, MD 21205.

Received for publication 21 September 1987 and in revised form 9 June 1988.

J. Clin. Invest.

(C) The American Society for Clinical Investigation, Inc 0021-9738/88/12/2011/06 \$2.00

Volume 82, December 1988, 2011-2016 can be anticipated that there will be large groups of humans and animals that will not respond efficiently to oral immunization with attenuated rotaviruses due to immunologic immaturity or deficiency $(13,14,17,18)$, consumption of milk containing rotaviral antibodies $(19,20)$, nutritional deficiencies (21), or interference with rotaviral replication due to the replication of other intestinal viruses (22). Furthermore, the antigenic determinants of a protective immune response have not been completely delineated. Additionally, active immunization would probably not be capable of altering the course of serious cases of rotavirus gastroenteritis once the infection is established. Thus, development of antiviral agents that inhibit the intestinal replication of a wide range of rotaviruses independent of the development of an immune response would be a useful alternative strategy for the prevention and treatment of rotaviral infections in high-risk populations.

It has been known for several years that trypsin and other intestinal proteases enhance the replication of rotaviruses in vitro $(23,24)$ and probably also in vivo $(25)$. This activation is the result of the cleavage of viral polypeptides located on the outer shell of the virus with a subsequent increase in the efficiency of cellular attachment or viral uncoating $(26,27)$. It is believed that the same process occurs in the small intestine, where a high level of protease activity exists and which is the principal site of rotaviral replication. Recently, a number of low-molecular weight aromatic diamidines that are potent inhibitors of trypsin-like proteases have been synthesized (28, 29). One of these compounds, bis (5-amidino-2-benzimidazolyl) methane (BABIM), ${ }^{1}$ is the most potent synthetic, reversible inhibitor of trypsin yet identified. This compound has been reported to possess a significant suppressive effect on the in vitro cytopathology and in vitro and in vivo yield of respiratory syncytial virus, a respiratory virus that requires proteolysis for efficient replication (30-32). We thus investigated the effect of BABIM, and a variety of drugs that inhibit protease function on the in vitro replication of rotavirus as well as on the replication of rotavirus in the intestinal tract of experimental animals.

\section{Methods}

Viruses. The SA-11 strain that we used was originally obtained from Dr. H. Malherbe, University of Texas, San Antonio, Texas. The virus was plaque purified and serially passaged in MA-104 cells using MEM containing $0.5 \mu \mathrm{g} / \mathrm{ml}$ of porcine trypsin (Sigma Chemical Co., St. Louis, MO) by means of previously described methods (33). The strain that we used can be propagated in MA-104 cells in roller tubes without additional trypsin but requires the presence of trypsin for the generation of visible plaques.

1. Abbreviations used in this paper: BABIM, bis (5-amidino-2-benzimidazolyl); EDIM, epizootic diarrhea of infant mice; MID $_{100}, 100 \%$ mouse infective dose. 
For some experiments, an aliquot of SA-11 was passaged three times in MA-104 cells in MEM without trypsin to generate a population of virus that was not trypsin activated. At the same time, an equivalent aliquot was passaged under identical conditions in the presence of trypsin. These strains were designated $\mathrm{SA}^{\mathrm{t}^{-}}$and $\mathrm{SA}^{\mathrm{t}}$, respectively. The virus was passaged at a dilution of $1: 10$ at each step. The final concentration of trypsin in the $\mathrm{SA}^{\mathrm{t}-}$ aliquots was thus $<0.001$ $\mu \mathrm{g} / \mathrm{ml}$.

Murine rotavirus or epizootic diarrhea of infant mice (EDIM) virus used for the animal experiments was originally obtained from Dr. Michael Collins, Microbiological Associates, Bethesda, MD. Virus for mouse inoculation was isolated from EDIM virus containing intestinal homogenates and purified on $\mathrm{CsCl}$ gradients using procedures previously described (34). The infectivity of the purified virus was determined by orally inoculating litters of 5-6-d-old mice with $10 \mu \mathrm{l}$ of serial 10-fold dilutions of the viral preparation. $3 \mathrm{~d}$ later, mice were evaluated for diarrhea by examining the distal colon for the presence of bright yellow, liquid contents that are characteristic of EDIM virus-induced diarrhea. The highest dilution of the viral preparation that resulted in diarrhea in all of the animals in the litter was defined as the $100 \%$ mouse infectious dose $\left(\mathrm{MID}_{100}\right)$.

Animals. Pregnant CD-1 mice were purchased from a commercial supplier (Charles River Breeding Laboratories, Inc., Portage, MI). All animals were bled at the time of arrival to assure that they were free of rotaviral antibodies. The mice were then placed in individual cages in positive pressure ventilation isolators, given food and water ad lib., and allowed to give birth naturally. At the beginning of each experiment, sera, and intestines were collected from two suckling mice in each litter to assure that the animals had remained free of serum rotaviral antibodies and intestinal rotaviral antigen. Suckling mice from all litters were combined and randomly divided equally among the dams in preparation for experimental inoculation. Suckling mice remained with the dams throughout the experiments.

Test compounds. The following protease inhibitors were obtained from Sigma Chemical Co., St. Louis, MO or Peninsula Laboratories, Santa Clara, CA: soybean trypsin inhibitor, human alpha-1-antitrypsin, antipain, bestatin, leupeptin, and chymostatin. Pentamidine and BABIM were synthesized according to previously described methods $(28,29)$.

Plaque assays. The effect of the various protease inhibitors on the growth of the SA-11 strain of rotavirus was determined by plaque inhibition methods performed by a modification of previously described rotavirus plaquing techniques (35). Briefly, SA-11 virus diluted to a concentration of $\sim 100$ plaque-forming units per milliliter in MEM without added serum was mixed with an equal volume of protease inhibitor at varying concentrations and adsorbed on MA-104 cell monolayers for $2 \mathrm{~h}$ at $37^{\circ} \mathrm{C}$. This mixture was then decanted and the cells were covered with agarose containing trypsin at a concentration of $0.5 \mu \mathrm{g} / \mathrm{ml}$, as well as the same concentration of protease inhibitor used in the absorptions. A second overlay containing the vital stain neutral red was added $3 \mathrm{~d}$ later and plaques representing infected cells that did not take up the vital stain were counted using standard methods. For each concentration of inhibitor, a percentage inhibition was calculated by comparisons with the number of plaques generated in wells processed in an identical fashion in the absence of protease inhibitor.

Animal inoculation. The effect of protease inhibitors on the in vivo replication of rotaviruses was evaluated in the mouse model of rotaviral infection. To do this, nine parts of a selected test compound diluted with PBS containing $0.01 \% \mathrm{CaCl}_{2}$ and $0.01 \% \mathrm{MgCl}_{2} \cdot 6 \mathrm{H}_{2} \mathrm{O}$ (Ca, Mg-PBS) to a concentration of $10 \mathrm{mg} / \mathrm{ml}$ was mixed with one part of EDIM virus containing 100 MID $_{100}$ of EDIM virus. $2 \mathrm{~d}$ after viral inoculation, the distal colon of each mouse was examined for the presence of liquid contents and the entire intestinal tract was collected for quantitation of rotaviral antigen by enzyme immunoassay.

Intestinal specimens. Intestinal tracts collected from suckling mice were wrapped individually, and immediately frozen at $-70^{\circ} \mathrm{C}$. In preparation for rotavirus antigen measurement by enzyme immunoassay, the individual samples were ground in hand-held, Ten Broeck type tissue grinders (CVWR Scientific, Bridgeport, NJ) and suspended in sufficient $\mathrm{Ca}, \mathrm{Mg}$-PBS to produce a $10 \%(\mathrm{wt} / \mathrm{vol})$ suspension. After a second freezing and thawing, the samples were centrifuged at $12,000 \mathrm{~g}$ for $5 \mathrm{~min}$ to pellet particulate material. The resulting supernatants were collected for enzyme immunoassay.

Immunoassays. A solid phase, sandwich-type, enzyme immunoassay was used to quantitate rotaviral antigens in murine intestinal homogenates. Wells of polystyrene microtiter plates (Immulon II; Dynatech Laboratories, Alexandria, VA) were first coated with either nonimmune chicken serum or chicken anti-EDIM virus serum that had been diluted in carbonate buffer ( $\mathrm{pH}$ 9.8). After overnight incubation at $4^{\circ} \mathrm{C}$, the wells were washed with PBS containing $0.5 \%$ Tween 20 (PBS-Tween), covered with test intestinal homogenate, and again incubated overnight at $4^{\circ} \mathrm{C}$. The wells were then washed with PBSTween and the quantity of rotaviral antigen bound to the antibodycoated solid phase was determined by the addition of guinea pig antiserum to EDIM virus, followed by affinity-purified, peroxidaselabeled, goat antibody to guinea pig IgG, and substrate consisting of 0.4 $\mathrm{mg}$ of $o$-phenylenediamine and $0.4 \mu \mathrm{l}$ of $30 \% \mathrm{H}_{2} \mathrm{O}_{2} / \mathrm{ml}$ of $0.01 \mathrm{M}$ citrate buffer ( $\mathrm{pH} 5.0$ ). The action of enzyme on substrate was quantitated in a spectrophotometer (Biotek Instruments Inc., Burlington, VT) at a wavelength of $450 \mathrm{~nm}$. Pooled intestinal homogenates obtained from EDIM virus-free or EDIM virus-infected suckling mice served as the negative and positive controls, respectively on each plate. The net OD for each test sample was determined by subtracting the OD readings obtained from wells coated with nonimmune chicken serum from the OD readings obtained from wells coated with EDIM virus-immune chicken serum. To control for plate-to-plate variations in OD readings, rotaviral antigen levels in each test sample were expressed as a percent of the positive control samples on that particular plate. (It was noted that BABIM at concentrations of up to $1 \mathrm{mg} / \mathrm{ml}$ did not effect antigen measurement in the enzyme immunoassay.) Values obtained for test compound-treated and control-treated animals were compared by Wilcoxon Rank Sum analysis to determine if observed differences were statistically significant. Values for graphic display were determined by expressing the rotaviral antigen levels in test compound-treated animals as a percent of the mean rotavirus antigen level in the PBS-treated control animals. Generally, the intestinal contents of infected, untreated animals yielded OD values ranging from $0.8-1.0 \mathrm{U}$.

Preinoculation serum samples were analyzed for rotaviral antibodies using both antibody binding (36) and inhibition (37) enzyme immunoassays similar to those previously described.

Pharmacokinetics. The test compound, BABIM, was labeled with tritium- $\left[{ }^{3} \mathrm{H}\right]$ by tritium exchange methods (New England Nuclear, Boston, MA). The specific activity of the compound was $8.7 \times 10^{5}$ $\mathrm{cpm} / \mu \mathrm{g}$ BABIM. The $\left[{ }^{3} \mathrm{H}\right]$ BABIM $\left(10^{6}\right.$ counts $)$ was intragastrically administered to 8-12-d-old suckling mice via a 24-gauge gavage needle and at selected intervals, plasma, urine, stomach, intestinal wash, and small intestine were collected from each animal (three to four mice per time point). Specimens were weighed and digested with $2 \mathrm{ml} \mathrm{NCS}$ tissue solubilizer (Amersham Corp., Arlington Heights, IL) at $37^{\circ} \mathrm{C}$ for $48 \mathrm{~h}$ with occasional shaking. The digest was neutralized with glacial acetic acid ( $34 \mu \mathrm{l} / \mathrm{ml}$ of NCS) and cooled to room temperature. $20 \mathrm{ml}$ of OCS liquid scintillant (Amersham Corp.) were added to each sample and the level of ${ }^{3} \mathrm{H}$ was determined in a liquid scintillation counter. The distribution of the ${ }^{3} \mathrm{H}$ label in each organ was expressed as counts per minute per 100 milligrams of tissue and was referred to as the raw counts per minute. To compensate for variation in weight of the mice at the termination of the experiment, the compensated counts per minute was determined by the formula: compensated counts per minute $=$ raw counts per minute $\times$ (individual body weight at termination of experiment/mean body weight of all mice at start of experiment).

\section{Results}

The effect of protease inhibitors on the in vitro replication of SA-11 virus is depicted in Fig. 1. Most of the protease inhibi- 


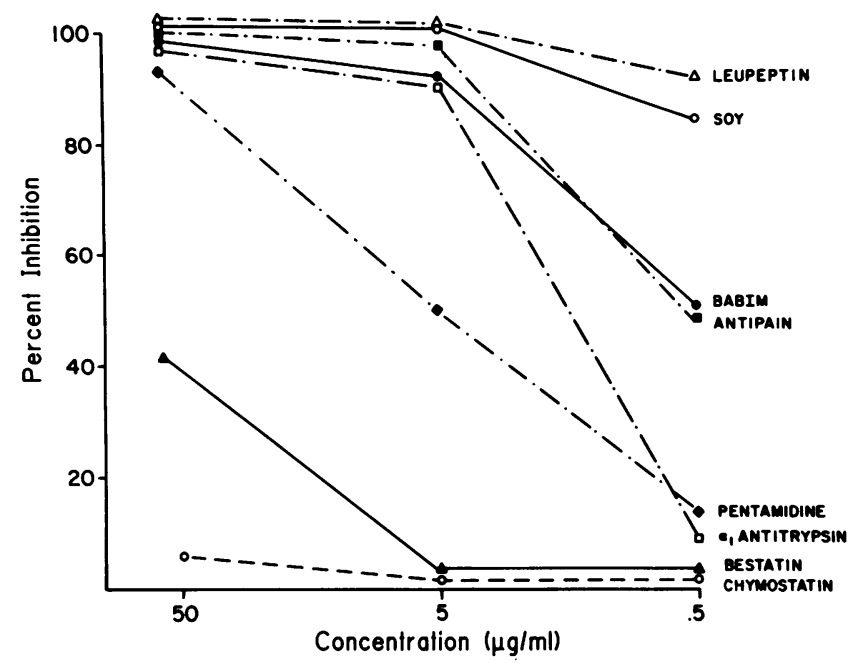

Figure 1. Effects of various protease inhibitors on the in vitro replication of SA-11 rotavirus in MA-104 cells. The measurements were performed as described in the text. Each point represents the degree of inhibition of SA-11 virus plaque formation induced by treatment with different concentrations of the protease inhibitors as compared with controls cultivated in the absence of inhibitor.

tors were capable of suppressing the in vitro replication of SA-11 virus at concentrations ranging from 0.5 to $5 \mu \mathrm{g} / \mathrm{ml}$. Efficacy was noted with macromolecular compounds such as alpha-1-antitrypsin and soybean trypsin inhibitor and with low molecular weight compounds such as leupeptin, BABIM, antipain, and to a lesser extent, pentamidine. Chymostatin, an inhibitor with specificity for chymotrypsin but no efficacy as a trypsin inhibitor, did not display any inhibitory activity against SA-11 virus.

We performed additional experiments to determine the relationship between proteolytic activation of virus and the efficacy of the protease antagonists for the inhibition of viral plaque formation. For these experiments we passaged a strain of plaque-purified SA-11 in MA-104 cells without trypsin, designated strain $\mathrm{SA}^{\mathrm{t}-}$, and we passaged the same strain of SA-11 in MA-104 cells in the presence of trypsin at a concentration of $1 \mu \mathrm{g} / \mathrm{ml}\left(\mathrm{SA}^{\mathrm{t+}}\right)$. After three passages, the effects of BABIM on the generation of plaques were assayed in a manner similar to the other experiments. As depicted in Fig. 2, BABIM inhibited both the $\mathrm{SA}^{\mathrm{t+}}$ and the $\mathrm{SA}^{\mathrm{t}-}$ strains at concentrations of 5 and 1 $\mu \mathrm{g} / \mathrm{ml}$. However, the inhibition achieved in the case of the $\mathrm{SA}^{\mathrm{t}-}$ strain was slightly greater than the inhibition noted with the $\mathrm{SA}^{\mathrm{t+}}$ strain $(93$ as opposed to $70 \%$ inhibition at a BABIM concentration of $5 \mu \mathrm{g} / \mathrm{ml}$ ). The ability of BABIM to inhibit the replication of the $\mathrm{SA}^{\mathrm{t}}$ strain was decreased to the level noted for the $\mathrm{SA}^{\mathrm{t}+}$ strain by the pretreatment of the virus with trypsin immediately before infection of the cells. This effect was reversed by the simultaneous addition of BABIM along with the trypsin in the preincubation (Fig. 2).

The effect of protease inhibitors on the in vivo replication of rotavirus is depicted in Fig. 3. Mice receiving EDIM virus that had been pretreated with leupeptin, pentamidine, BABIM, antipain, or alpha-1-antitrypsin had significantly less diarrhea than the $\mathrm{Ca}, \mathrm{Mg}$-PBS-treated control animals. Additionally, markedly lower levels of intestinal rotaviral antigens were present in animals administered virus pretreated with leupeptin, pentamidine, or BABIM when compared with the

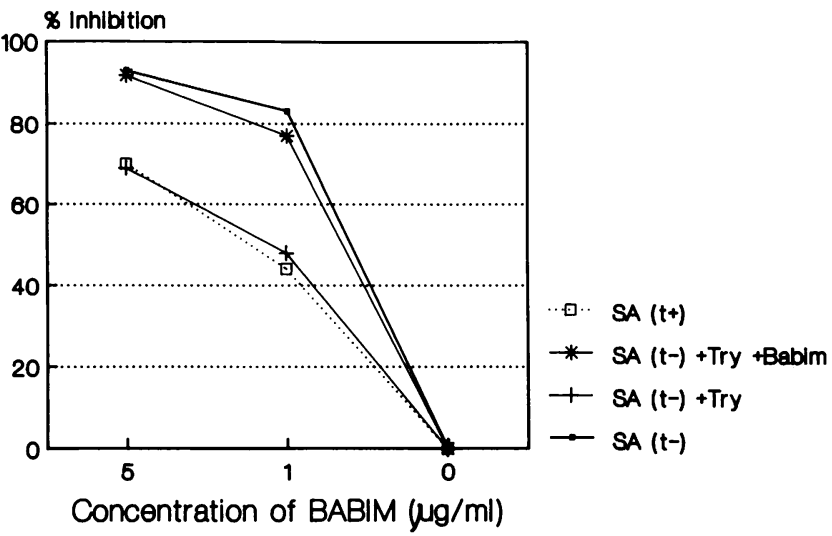

Figure 2. Effect of BABIM on the replication of SA-11 cultivated in the presence and absence of trypsin. An aliquot of plaque-purified SA-11 was passed three times in MA-104 cells in roller tubes in the absence of trypsin, and an aliquot from the same source was passed three times in the presence of trypsin under cultivation conditions that were otherwise identical. These strains, designated SA $(t-)$ and SA $(t+)$ respectively, were used to infect MA-104 cells in 12-well tissue-culture plates in the presence and absence of BABIM and the amount of inhibition of plaque formation was quantitated as described in the text. In addition, an aliquot of the $S A(t-)$ strain was activated with trypsin for $120 \mathrm{~min}$ at $37^{\circ} \mathrm{C}$ immediately before infection (SA ( $t-)+$ Try) and another aliquot was incubated simultaneously without trypsin and BABIM for $120 \mathrm{~min}$ at $37^{\circ} \mathrm{C}$ immediately before infection (SA $(\mathrm{t}-)+$ Try + BABIM). These treated strains were added to the MA-104 cells and the number of plaques generated was quantitated in a manner identical to that of the other strains.

control animals. Animals given antipain-treated virus had intermediate levels of intestinal rotaviral antigen. Although significantly less diarrhea was present in mice receiving alpha-1antitrypsin-treated EDIM virus, the levels of intestinal rotaviral antigen did not significantly differ from control animals. The compound BABIM was selected for further studies since, as noted above, it is an extremely potent inhibitor of trypsin

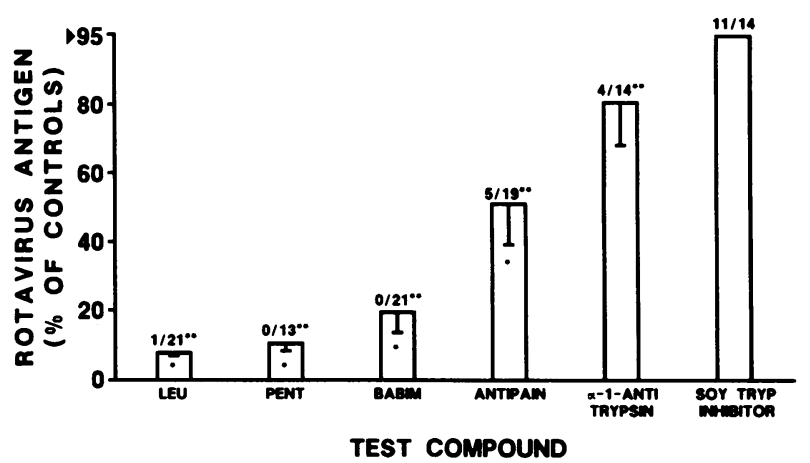

Figure 3. Effects of various protease inhibitors on the in vivo replication of EDIM virus. Protease inhibitor at a concentration of 10 $\mu \mathrm{g} / \mathrm{ml}$ was mixed with EDIM virus, incubated at $37^{\circ} \mathrm{C}$ for $30 \mathrm{~min}$ and then fed to suckling mice. Each bar represents the mean rotaviral antigen level $( \pm$ SEM $)$ in intestinal homogenates obtained from test compound treated mice $2 \mathrm{~d}$ after EDIM virus inoculation. Data are expressed as a percentage of the mean rotaviral antigen level in PBS-treated control animals. Numbers above each bar represent number of diarrheic mice/total mice examined, *, significantly different $(P<0.05)$ from controls by Wilcoxon Rank Sum Test. **, significantly different $(P<0.05)$ from controls by Fisher's Exact Test. 
and has been shown to have inhibitory activity for other pathogenic viruses (30-32).

Additional studies in animals were directed at determining the kinetics of BABIM protection. Thus, a single dose of $10 \mu \mathrm{l}$ of BABIM $(10 \mathrm{mg} / \mathrm{ml})$ was administered orally to $3-7-\mathrm{d}$-old suckling mice either one-half, 1 , or $2 \mathrm{~h}$ before or one-half, 1 , or 2 hours after $1 \mathrm{MID}_{100}$ of EDIM virus was administered. Only when BABIM was given one-half hour before virus was the rotaviral replication inhibited (data not shown).

Because it appeared that BABIM had to be administered at the time of viral infection or shortly before viral infection to maximally inhibit replication, we decided to determine if repeated administration of BABIM following viral inoculation would inhibit subsequent rotaviral replication. To make this determination, 7-10-d-old suckling mice were inoculated with $1 \mathrm{MID}_{100}$ of murine rotavirus. Beginning either one-half, 2, 24, or $48 \mathrm{~h}$ after viral inoculation, $10 \mu \mathrm{l}$ of BABIM $(10 \mathrm{mg} / \mathrm{ml})$ was administered at 9 and 11 a.m. and at 1,3 , and 5 p.m. every day for the course of the study. Control mice were administered $\mathrm{Ca}, \mathrm{Mg}$ PBS at the same times. Rotaviral antigen levels in intestinal homogenates were determined by enzyme immunoassay 2 and $4 \mathrm{~d}$ after viral inoculation. Significantly lower levels of rotaviral antigen were found $2 \mathrm{~d}$ after viral inoculation in mice treated with BABIM beginning one-half, 2, or 24 $h$ after EDIM virus inoculation when compared with control animals treated with PBS (Fig. 4). Viral replication was also significantly inhibited $4 \mathrm{~d}$ after viral inoculation in mice given BABIM beginning either 2 or $48 \mathrm{~h}$ after rotaviral administration (Fig. 4).

The effect of BABIM on animal to animal transmission of rotavirus was also examined. For this purpose, each of five litters (8-12 animals per litter) of 5-7-d-old suckling mice were divided into equal thirds. One third of each litter was orally inoculated with $100 \mathrm{MID}_{100}$ of EDIM virus only. One third was given $10 \mu \mathrm{l}$ of $\mathrm{Ca}, \mathrm{Mg}$ PBS orally every day at 9 and 11 a.m. and 1, 3, and 5 p.m., and one third was given $10 \mu \mathrm{l}$ of BABIM $(10 \mathrm{mg} / \mathrm{ml})$ orally at the same times. 3 and $5 \mathrm{~d}$ after

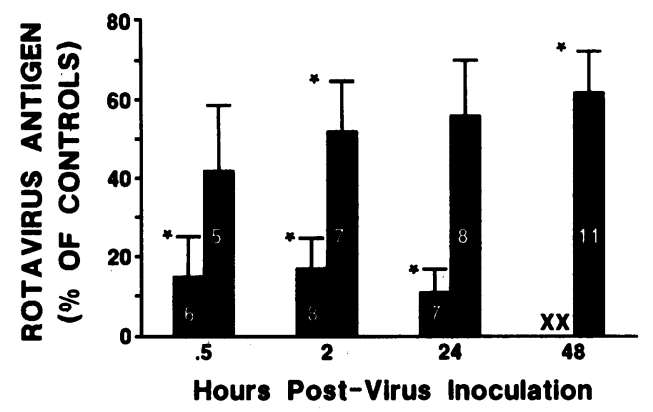

Figure 4. Effects of repeated BABIM administration on the replication of rotavirus in suckling mice. $10 \mu \mathrm{l}$ of BABIM $(10 \mu \mathrm{g} / \mathrm{ml})$ or $\mathrm{Ca}$, Mg PBS were administered to suckling mice at 9 and 11 a.m. and at 1,3 , and 5 p.m. beginning either $0.5,2,24$, or $48 \mathrm{~h}$ after EDIM virus inoculation. Each pair of bars represents the mean rotaviral antigen level $( \pm$ SEM) in intestinal homogenates obtained from BABIM treated mice at 2 (first bar) or 4 (second bar) d after EDIM virus inoculation. Data are expressed as a percentage of the mean rotaviral antigen level in PBS treated control animals. The number inside each bar represents the number of animals tested. $X X$, animals in this group had not received BABIM at $2 \mathrm{~d}$ postviral inoculation. *, significantly different $(P<0.05)$ from controls by Wilcoxon Rank Sum Test.

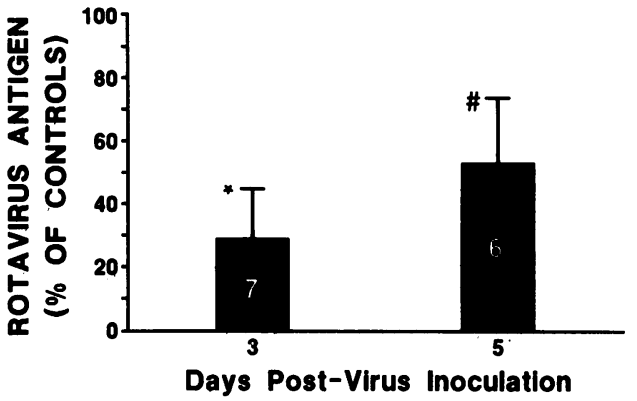

Figure 5. Effects of BABIM administration on rotaviral transmission in suckling mice. Each of five litters of suckling mice were divided into equal thirds. One third of each litter was given EDIM virus only. One third of each litter was administered $10 \mu \mathrm{l}$ of BABIM (10 $\mathrm{mg} / \mathrm{ml}$ ) daily at 9 and $11 \mathrm{a} . \mathrm{m}$. and at 1,3 , and $5 \mathrm{p} . \mathrm{m}$. The remaining third of each litter served as controls and were inoculated with $\mathrm{Ca}$, $\mathrm{Mg}$ PBS at the same times. Each bar represents the mean rotaviral level $( \pm$ SEM) in intestinal homogenates obtained from BABIMtreated mice. Data are expressed as a percentage of the mean rotaviral antigen level in PBS treated control animals. *, significantly different $(P<0.05)$ from controls by Wilcoxon Rank Sum Test. \#, significantly different $(0.05<P<0.1)$ from controls by Wilcoxon Rank Sum Test.

rotaviral inoculation, intestinal tracts were collected and the quantity of rotaviral antigen was determined by enzyme immunoassay. As expected, the virus-inoculated animals transmitted virus to the uninoculated groups; however, $3 \mathrm{~d}$ after viral inoculation mice given BABIM had significantly lower levels of viral antigen than did control mice as determined by the Wilcoxon Rank Sum Test (Fig. 5). 2 d later, the BABIM treated mice still had lower levels of rotaviral antigen than did the PBS-treated controls; however, the difference at day 5 did not reach statistical significance.

We also used radiolabeled BABIM to investigate the pharmacokinetics of the drug in the murine model. After intragastric administration of $\left[{ }^{3} \mathrm{H}\right] \mathrm{BABIM}$, the ${ }^{3} \mathrm{H}$ label was rapidly

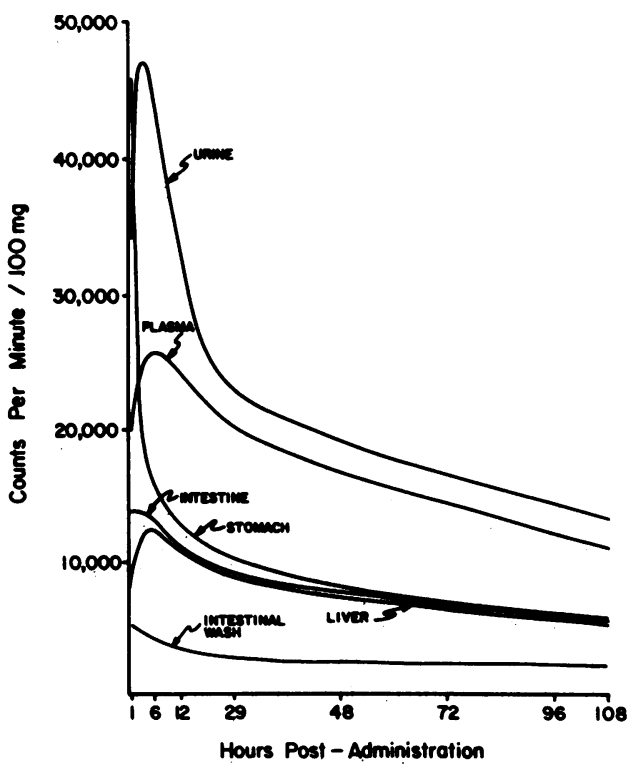

Figure 6. Distribution of ${ }^{3} \mathrm{H}$ in tissues and body fluids after intragastric administration of $10^{6}$ counts of $\left[{ }^{3} \mathrm{H}\right] \mathrm{BABIM}$. 
detected in all tissues and body fluids examined (Fig. 6). High levels of label were initially present in the stomach; however, comparable levels were not found at any other point in the gastrointestinal tract or in the intestinal washings. Instead, the quantity of label in the stomach declined as the label began to appear in high concentration in plasma and urine.

\section{Discussion}

Our studies indicate that a number of protease inhibitors suppressed rotaviral replication in vitro and also restricted rotaviral replication in vivo when administered simultaneously with virus. In addition, BABIM inhibited viral replication if administered in multiple doses after rotaviral infection and also limited the transmission of infection in a heavily contaminated environment. Repeated administration of BABIM at the levels used in the present studies caused an alteration in consistency of the colonic contents of the suckling mice; the rotaviral disease status thus could not be accurately assessed. The change of fecal consistency may reflect protein maldigestion due to inhibition of pancreatic and cellular proteases by BABIM. Additional studies should be directed at determining the pharmacokinetics, toxicology, and efficacy of protease inhibitors. Of particular importance will be the determination of potential adverse effects of protease inhibitors on host nutrition and cellular metabolism.

The mechanism by which BABIM and other protease inhibitors limit the in vivo and in vitro replication of rotaviruses is most likely related to their ability to impede the proteolytic modification of virion or cellular polypeptides that is required for efficient cellular penetration and cell-to-cell spread $(30-32)$. In the case of the in vitro system used for these experiments, the efficacy of the compounds for the inhibition of rotaviral replication is probably a direct reflection of the compounds' ability to inhibit exogenous trypsin. However, it is of note that some of the compounds that displayed good levels of in vitro inhibitory activity, such as alpha-1 antitrypsin, soy inhibitor and antipain had little effect on the in vivo replication of rotaviruses in experimentally infected animals. The reason for the differences between the in vitro and in vivo efficacy of protease inhibitors is not known with certainty but might be related to differences in pharmacokinetics, solubility, or cellular penetration, or to differences in the substrate specificities of the trypsin used in the in vitro experiments and the mixture of proteolytic enzymes found in the gastrointestinal tract. The exact mechanism of action of the protease inhibitors as well as the nature of the cellular and viral proteases involved in rotavirus replication should be the subject of additional investigations.

Little information is currently available concerning the in vitro or in vivo pharmacokinetics of BABIM or other diamidine protease inhibitors. Our preliminary studies, used a radiolabeled BABIM preparation, suggested that orally administered BABIM was rapidly absorbed from the stomach of suckling mice and then excreted in the urine. Since we measured total ${ }^{3} \mathrm{H}$ activity rather than specific $\left[{ }^{3} \mathrm{H}\right] \mathrm{BABIM}$, it is possible that we were also measuring ${ }^{3} \mathrm{H}$-labeled metabolic products of BABIM in addition to the active drug. More detailed studies on the pharmacokinetics of BABIM and related compounds should allow for more efficient dosing regimens and formulations. However, our finding of a prolonged serum half-life and wide volume of distribution suggests that the administration of these compounds might be a practical means for the prevention or treatment of infections with susceptible viruses.

We found that the protease antagonists could inhibit the in vitro generation of rotavirus plaque formation, even when the infecting virions were preactivated by growth in trypsin (Fig. 2). This finding suggests that protease antagonists can interfere with the cell-to-cell transmission of rotavirus infection even in situations in which the viral surface proteins are already activated by proteolytic cleavage $(26,27)$. Furthermore, since the strain of pathogenic murine rotavirus which we used for our in vivo studies has been serially passaged by the intestinal infection of mice, it is likely that this virus was also activated by intestinal proteases before administration to the experimental animals. It is thus likely that, even in situations in which the administration of BABIM does not prevent the entry of virus into cells and the primary cycle of replication, the presence of the drug might impede the generation of virions capable of infecting additional cells and sustaining viral infection.

Most available chemotherapeutic agents directed at the inhibition of viral replication exert their activity by the inhibition of viral nucleic acid synthesis. Since there are many shared pathways of viral and mammalian nucleotide metabolism, these agents have the potential of interfering with nucleic acid synthesis in host cells. It is thus difficult to determine with certainty that the drugs do not have mutagenic or carcinogenic potential, a fact which makes many of the currently available antiviral drugs difficult to apply to the widespread treatment of childhood viral infections. Although this mode of action cannot be entirely ruled out for BABIM, it seems unlikely in light of the studies of the inhibitory effect of BABIM on the replication of respiratory syncytial virus. In this instance, it was shown that BABIM delays viral penetration into cells by its antiprotease action but does not interfere with viral RNA replication (30-32). Protease inhibitors such as the ones described in this report represent a new class of viral agents that functions at the level of protein interactions and would not be expected to have such potential for long-term untoward effects on mammalian nucleic acids. In addition, many pathogenic viruses, including myxoviruses (38), paramyxoviruses (39), retroviruses (40), coronaviruses (41), and poxviruses (42), require viral or host proteases for productive infection. Thus, chemotherapeutic agents which possess protease inhibitory activity may have a broad range of antiviral activity. The availability of antiviral agents capable of inhibiting a wide range of pathogenic viruses without interfering with host nucleic acid replication may represent a major advance in the prevention and treatment of viral infections in humans and other animals.

\section{References}

1. Estes, M. K., E. L. Palmer, and J. F. Obijeski. 1983. Rotavirus. A review. Curr. Top. Microbiol. Immunol. 105:123-184.

2. Flewett, T. H., and G. N. Woode. 1978. The rotaviruses. Arch. Virol. 57:1-23.

3. McNulty, M. S. Rotaviruses. 1978. J. Gen. Virol. 40:1-183.

4. Greenberg, H. B., R. G. Wyatt, A. R. Kalica, and R. H. Yolken. 1981. New insights in viral gastroenteritis. Perspectives Virol. 11:163188.

5. Kapikian, A. Z., H. W. Kim, R. G. Wyatt, W. L. Cline, J. O. Arrobio, C. D. Brandt, W. J. Rodriquez, D. A. Sack, R. M. Chanock, and R. H. Parrott. 1976. Human reovirus-like agent as the major pathogen associated with "winter" gastroenteritis in hospitalized infants and young children. N. Engl. J. Med. 294:915-972. 
6. Mata, L. J., and R. G. Wyatt. 1971. The uniqueness of human milk. Host resistance to infection. Am. J. Clin. Nutr. 24:976-986.

7. Kaplan, J. E., L. B. Schonberger, G. Varano, N. Jackman, J. Bied, and G. W. Gary. 1982. An outbreak of acute nonbacterial gastroenteritis in a nursing home. Am. J. Epidemiol. 116:940-948.

8. Marie, T. J., S. H. S. Lee, R. S. Faulkner, J. Ethier, and C. H. Young. 1982. Rotavirus infection in a geriatric population. Arch. Intern. Med. 142:313-316.

9. Keswick, B. H., N. R. Blacklow, G. Cukor, H. L. DuPont, and J. L. Vollet. 1982. Norwalk virus and rotavirus in traveler's disease in Mexico. Lancet. i:109-110.

10. Vollet, J. J., C. D. Ericsson, G. Gibson, L. K. Pickering, H. L. DuPont, S. Kohl, and R. H. Conklin. 1979. Human rotavirus in an adult population with Travelers' Disease and its relationship to the location of food consumption. J. Med. Virol. 4:81-87.

11. Kim, H. W., C. D. Brandt, A. Z. Kapikian, and R. G. Wyatt. 1977. Human reovirus-like agent (HRVLA) infection: occurrence in adult contacts of pediatric patients with gastroenteritis. JAMA (J. Am. Med. Assoc.). 238:404-407.

12. VonBonsdorff, C. H., T. Havi, P. Makela, and A. Morttimer. 1978. Rotavirus infections in adults in association with acute gastroenteritis. J. Med. Virol. 2:21-28.

13. Losonsky, G., J. Johnson, J. A. Winkelstein, and R. H. Yolken. 1986. The oral administration of human serum immunoglobulin in immunodeficient patients with viral gastroenteritis: a pharmacokinetic and functional analysis. J. Clin. Invest. 76:2362-2367.

14. Saulsbury, F. T., J. A. Winkelstein, and R. H. Yolken. 1980. Chronic rotavirus infection in immunodeficiency. J. Pediatr. 97:6165.

15. Kapikian, A. Z., K. Midthun, Y. Hoshino, J. Flores, R. G. Wyatt, R. I. Glass, J. Askaa, O. Nakagomi, T. Nakagomi, R. M. Chanock, M. M. Levine, M. L. Clements, R. Dolin, R. Wright, R. B. Belshe, E. L. Anderson, and L. Potash. 1985. Rhesus rotavirus: A candidate vaccine for prevention of human rotavirus disease. In Molecular and Chemical Basis of Resistance to Parasitic, Bacterial, and Viral Disease. R. H. Lerner, R. M. Chanock, and F. Brown, editors. Cold Spring Harbor Laboratory, Cold Spring Harbor, NY. 357-367.

16. Vesikari, T., E. Isolauri, E. D'Hondt, A. Delem, F. E. Andre, and G. Zissis. 1984. Protection of infants against rotavirus diarrhea by RIT 4237 attenuated bovine rotavirus strain vaccine. Lancet. i:977981.

17. Rosen, F. S., and C. A. Janeway. 1964. Dangers of vaccination in lymphopenic infants. Pediatrics. 33:310-311.

18. Yolken, R. H., C. A. Bishop, T. R. Townsend, E. A. Bolyard, J. Bartlett, G. W. Santos, and R. Saral. 1982. Infectious gastroenteritis in bone marrow-transplant recipients. N. Engl. J. Med. 306:1009-1012.

19. Cukor, G., N. R. Blacklow, F. E. Capozza, Z. F. K. Panjvani, and F. Bednarek. 1979. Persistence of antibodies to rotavirus in human milk. J. Clin. Microbiol. 9:93-96.

20. Yolken, R. H., R. G. Wyatt, L. Mata, J. J. Urrutia, B. Garcia, R. M. Chanock, and A. Z. Kapikian. 1978. Secretory antibody directed against rotavirus in human milk. Measurement by means of enzymelinked immunosorbent assay. J. Pediatr. 93:916-921.

21. Brown, R. E., and M. Katz. 1966. Failure of antibody production to yellow fever vaccine in children with kwashiorkor. Trop. Georg. Med. 18:125-128.

22. John, T. J., and S. Christopher. 1975. Oral polio vaccination of children in the tropics: III. Intercurrent enterovirus infections, vaccine virus take and antibody response. Am. J. Epidemiol. 102:422-429.

23. Babiuk, L. A., K. Mohammed, L. Spence, M. Fauvel, and R.
Petro. 1977. Rotavirus isolation and cultivation in the presence of trypsin. J. Clin. Microbiol. 6:610-617.

24. Theil, K. W., and E. H. Bohl. 1980. Porcine rotaviral infection of cell culture: Effects of certain enzymes. Am. J. Vet. Res. 41:140-143.

25. Steel, R. B., and A. Torres-Medina. 1984. Effects of environmental and dietary factors on human rotavirus infection in gnotobiotic piglets. Infect. Immun. 43:906-911.

26. Clark, S. M., J. R. Roth, M. L. Clark, B. B. Barnett, and R. S. Spendlove. 1981. Trypsin enhancement of rotavirus infectivity: mechanism of enhancement. J. Virol. 39:816-822.

27. Estes, M. K., D. Y. Graham, and B. B. Mason. 1981. Proteolytic enhancement of rotavirus infectivity: molecular mechanisms. $J$. Virol. 39:879-888.

28. Geratz, J. D., A. C. Whitmore, M. C. F. Cheng, and C. Piantadosi. 1973. Diamidino-, -diphenoxylakanes. J. Med. Chem. 16:970978.

29. Tidwell, R. R., J. D. Geratz, O. Dann, G. Volz, D. Zeh, and H. Loewe. 1978. Diarylamidine derivatives with one or both of the aryl moieties consisting of an indole or indole-like ring. Inhibitors of arginine-specific esteroproteases. J. Med. Chem. 21:613-623.

30. Dubovi, E. J., J. D. Geratz, S. R. Shaver, and R. R. Tidwell. 1981. Inhibition of respiratory syncytial virus-host cell interactions by mono- and diamidines. Antimicrob. Agents Chemother. 19:649-656.

31. Dubovi, E. J., J. D. Geratz, and R. R. Tidwell. 1980. Inhibition of respiratory syncytial virus by bis ( 5 -amidino-2 benzimidazolyl) methane. Virology. 103:502-504.

32. Tidwell, R. R., J. D. Geratz, W. A. Clyde, K. W. Rosenthal, and E. J. Dubovi. 1984. Suppression of respiratory syncytial virus infection in cotton rats by bis (5-amidino-2benzimidazolyl) methane. Antimicrob. Agents. Chemother. 26:591-593.

33. Urasawa, T., S. Urasawa, and K. Taniguchi. 1981. Sequential passages of human rotavirus in MA-104 cells. Microbiol. Immunol. 25:1025-1035.

34. Vonderfecht, S. L., A. C. Huber, J. Eiden, L. C. Mader, and R. H. Yolken. 1984. Infectious diarrhea of infant rats produced by a rotavirus-like agent. J. Virol. 52:94-98.

35. Wyatt, R. G., and W. D. James. 1982. Methods of gastroenteritis virus culture in vivo and in vitro. Inf. Dis. Antimicrob. Agents. 3:13-35.

36. Sheridan, J., R. S. Eydelloth, S. L. Vonderfecht, and L. Aurelian. 1983. Virus-specific immunity in neonatal and adult mouse rotavirus infections. Infect. Immun. 39:917-927.

37. Eydelloth, R. S., S. L. Vonderfecht, J. F. Sheridan, L. Enders, and R. H. Yolken. 1984. Kinetics of viral replication and local and systemic immune responses in experimental rotavirus infection. $J$. Virol. 50:947-950.

38. Zhirnov, O. P., A. V. Ovcharenko, and A. G. Bukrinskaya. 1984. Suppression of influenza virus replication in infected mice by protease inhibitors. J. Gen. Virol. 65:191-196.

39. Muramatsu, M., and M. Homma. 1980. Trypsin action on the growth of Sendai virus in tissue culture cells. V. An activating enzyme for Sendai virus in the chorioallantoic fluid of the embryonated chicken egg. Microbiol. Immunol. 24:113-122.

40. Andersen, K. B. 1983. Leupeptin inhibits retrovirus infection in mouse fibroblasts. $J$. Virol. 48:765-769.

41. Appleyard, G., and M. Tisdale. 1985. Inhibition of the growth of human coronavirus 229E by leupeptin. J. Gen. Virol. 66:363-366.

42. Ichihashi, Y., and M. Oie. 1982. Proteolytic activation of vaccinia virus for the penetration phase of infection. Virology. 116:297305. 